International Journal of Engineering \& Technology, $7(4.38)(2018) 1279-1281$
International Journal of Engineering \& Technology
SPC
Website: www.sciencepubco.com/index.php/IJET
Research paper

\title{
The Effects of Culture on Employee Performance (A Study in The Agent of Tele Account Management Unit, PT. Telecommunication Indonesia Regional VII Makassar)
}

\author{
Agung Augustrianto1, 2, Agus Rahayu1, Lili Adi Wibowo1 \\ ${ }^{1}$ School of Post Graduate Degree Universitas Pendidikan Indonesia, Bandung 40154, Indonesia \\ ${ }^{2}$ Lecturer at Universitas Widyatama, Bandung 40125, Indonesia \\ ${ }^{1}$ Lecturer at Universitas Pendidikan Indonesia, Bandung 40154, Indonesia \\ ${ }^{1}$ School of Post Graduate Degree Universitas Pasundan, Bandung 40171, Indonesia \\ ${ }^{2}$ Lecturer at Universitas Widyatama, Bandung 40125, Indonesia
}

\begin{abstract}
Organizational culture is an important factor affecting many aspects withinthe organization. Therefore, the aim of this research is to measure the relationship between organizational culture (such as clan, adhocracy, market, and hierarchy) and operational performance in the Tele Account Management Unit of PT. Telkom Indonesia Regional VII Makassar. Through the calculation using statistical tools, it was found that organizational culture had a simultaneous effect on the employee performance. And, the kind of culture implemented in this unit is the market culture.
\end{abstract}

Keywords: Organizational Culture, Adhocracy Culture, Clan Culture, Market Culture, Hierarchy Culture, Employee Performance

\section{Introduction}

Outsourcing is the utilization of labor from outside the company to do certain jobs. In this era, the utilization of outsourcing is common in businesses. As one of the prominent organizations in Indonesia, PT. Telekomunikasi Indonesia (Telkom) also uses outsourcing services in running their business. PT. Infomedia Nusantara as a subsidiary of Telkom Group with the specialization in outsourcing and contact center business distributes their agents to work in PT. Telkom, including in the Tele Account Management Unit of PT. Telkom Indonesia Regional VII in Makassar.

In general, each individual has their own cultural background which affects their behavior. Culture directs every individual to what things to be learned and followed. PT. Telkom Indonesia has also their own organizational culture tagged as "The Telkom Way". The meaning within the tag defines that PT. Telkom tries to do their best based on integrity, enthusiasm, and totality with the values of solidity, speed, smartness. These three words are implemented through the behaviours of Telkom's employees. The Telkom Way become the third pillar of corporate culture that contains 3P as the core elements, such as Philosophy, Principle, and Practice. Philosophy to be the Best is the basic belief that contains basic philosophies for every member of Telkom group through some behaviors, such as Integrity, Respect, Enthusiasm, Loyalty, and Totality. Principles to be the Star is to implemented behaviors of "Always The Best" and Practices to be the Winner is when Telkom members implemented the principal of Solid-Speed-Smart and at the end become the great people of Telkom.

With reference to the results of a pre-test study revealing that the organizational culture understanding of "The Telkom Way" and "solid, speed, smart (3S)" for tele account employees is very low despite their good performance in 2016. Based on 30 respondents, there are $36.7 \%$ employee in tele account unit who do not really understand about the meaning of Telkom's organizational culture. From all respondents, only $10 \%$ stated that they understand about Telkom's organizational culture.

Performance can be described as the level of achievement from activities or policies implementation in realizing organizational goals, objectives, vision and mission in an organization. According to the interview with management, from January until June 2016, the trend of selling target from tele account unit is declined. From the presence also known that in every month, from January to June 2016 the average of employee's lateness is $6 \%$.

Therefore, this research is aimed at finding out what the organizational culture and performance of the tele account employees look like, and how the relationship between organizational culture and employee performance is in the Tele Account Management Unit of PT. Telkom Indonesia Regional VII Makassar.

\section{Organizational Culture}

Every organization needs an organizational culture that basically becomes the guidance of how the organization act. Organizational culture is a common of value and belief that unites all members to work together in achieving organizational goals.

Organizational culture is a broad concept that can be interpreted in different ways, such as values, rules and practices ${ }^{1}$. Organizational culture is a long-lasting habit used and applied in work activities as one of the boosters to improve the work quality of employees and leaders in an organization ${ }^{2}$. A strong culture will help improve employee performance and ultimately increase the organizational performance too ${ }^{3}$. 
Culture in an organization can be functioned as ${ }^{4}$ (Sunyoto):

1. A process of internal integration, where members of an organization can be uniting, so they will understand how to interact with each other. The internal integration function will provide a person and other co-worker a collective identity as well as provide guidance on how one can cooperate effectively.

2. An external adaptation process, where the organizational culture will determine how the organization meets its various objectives and deals with outsiders. It will provide a level of organizational adaptation in response to changing times, competition, innovation, and service to consumers.

While in ${ }^{5}$ culture is divided into four types, namely; clan, adhocracy, market, and hierarchy. Another literature mentioned that in clan culture, leaders are regarded as the mentors and perhaps even as the parental figures. The organization emphasizes on the longterm benefits of individual development. The organization provides premiums on teamwork, participation, and consensus ${ }^{5}$. Adhocracy culture is related to an effective leadership in vision, innovation, and risk-taking. The emphasis is on being at the leading edge of new knowledge, products, and services. The organization's long-term priority is the rapid growth and the acquisition of new resources ${ }^{6}$. Leaders in market culture are the tough producers and competitors. The long-term concerns of market culture are on the competitive actions, and the achievement of strict goals and targets. While in a hierarchy culture, leadersare known as the people capable of being effective coordinators and organizers ${ }^{6}$. The long-term concerns of the organization are the stability, predictability, and efficiency. Formal rules and policies hold the organization together ${ }^{6}$

\section{Employee Performance}

Employee performance can be described as the ability of employees to reach goals, even it is an individual or an organizational goal using organizational resources efficiently and effectively ${ }^{5}$. Performance is a record of work or activity obtained within a certain time. There are some criteria that can be used to measure employee performance ${ }^{7}$ :

1. Quantity

Quantity is measured based on employee perception of the activities and outcomes.

2. Quality

Quality can be measured based on employee perception about the quality of work, skills and the ability to produce a perfect job.

3. Attendance

Work performance can be shown from the employee presence.

4. Employee cooperation

Employee cooperation is the ability of employees in working as a team, either vertically or horizontally.

Employee performance is gained through multifunctional coverage, such as human, technological, organizational and institutional levels ${ }^{8}$. Another literature also mentions thatthe financial or nonfinancial outcomes serve as an indicator of the employee performance, which has a direct effect on organizational performance ${ }^{8}$. Basically, employee performance is the outcome achieved and the ability to work.

According to ${ }^{9}$ (Sudarmanto), organizational culture is formed by the organizational subjective perceptions of the values of innovation, risk tolerance, team pressure, and support. The overall perception will shape the culture or personality of the organization. Furthermore, organizational culture will affect employee performance and satisfaction, whether supportive or non- supportive.

Based on the explanation above, this research will observe the r'elationship between organizational culture and employee per- formance. This study will use Hierarchy, Market, Clan, and Adhocracy Culture as an independent variable. While, employee's performance as a dependence variable will be measured with quantity, quality, employee's attendance, and employee's cooperation. Below is the theoretical framework of this research.

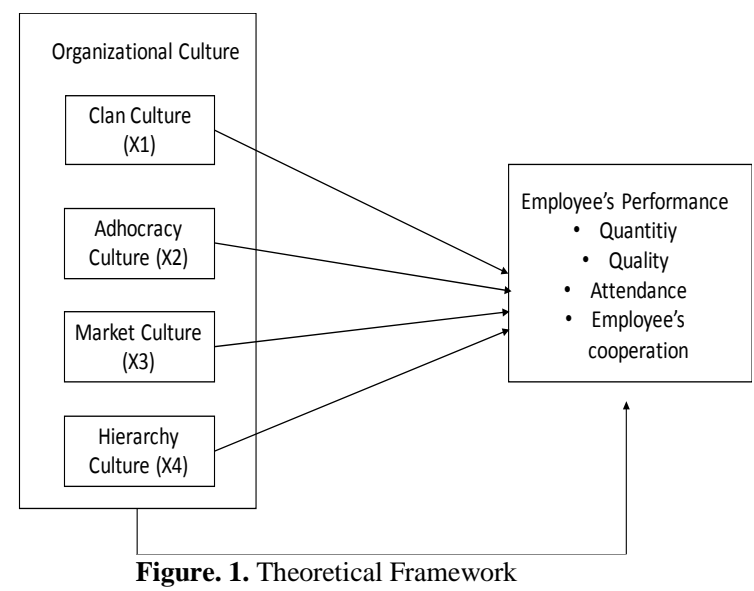

This research will find the partial and simultaneous relationships between organizational culture and employee performance. Hence, the hypotheses of this research are divided into five as follows:

1.Hypothesis 1: Clan culture has a significant relationship with employee performance.

2.Hypothesis 2: Adhocracy culture has a significant relationship with employee performance.

3.Hypothesis 3: Market culture has a significant relationship with employee performance.

4.Hypothesis 4: Hierarchy culture has a significant relationship with employee performance.

5.Hypothesis 5: Organizational culture has a significant relationship with employee performance.

\section{Results}

This research uses quantitative method. Based on the background and literature explanations, this research falls into a causal descriptive category. Through a descriptive method, this research will describe the phenomena taking place in the research object systematicallyin accordance with the actual facts ${ }^{10}$. According to ${ }^{11}$, causal relationship is a cause and effect connection. This relationship can be represented bythe independent and dependent variables.

This research views organizational culture as the independent variable, and employee performance as the dependent variable. The subjects of this research were employee of tele account management, and the questionnaires were given to 54 employees in the unit.

Through multiple regression method, the partial relationship between the variables are shown in table below. 
Table. 1. Partial Relationship Results

\begin{tabular}{|c|c|c|c|c|c|c|c|c|}
\hline \multicolumn{9}{|c|}{ Coefficients $^{\mathbf{a}}$} \\
\hline & \multirow{2}{*}{ Model } & \multicolumn{2}{|c|}{ Unstandardized Coefficients } & \multirow{2}{*}{$\frac{\text { Standardized Coefficients }}{\text { Beta }}$} & \multirow{2}{*}{$\mathrm{t}$} & \multirow{2}{*}{ Sig. } & \multicolumn{2}{|c|}{ Collinearity Statistics } \\
\hline & & $\mathrm{B}$ & Std. Error & & & & Tolerance & VIF \\
\hline \multirow{5}{*}{1} & (Constant) & -.030 & .256 & & -.117 & .908 & & \\
\hline & $\mathrm{x} 1$ & .255 & .136 & .246 & 1.876 & .067 & .341 & 2.935 \\
\hline & $\mathrm{x} 2$ & .198 & .171 & .202 & 1.159 & .252 & .193 & 5.180 \\
\hline & $\mathrm{x} 3$ & .482 & .118 & .490 & 4.098 & .000 & .411 & 2.431 \\
\hline & $\mathrm{x} 4$ & -.018 & .141 & -.019 & -.130 & .897 & .289 & 3.464 \\
\hline
\end{tabular}

Based on the partial hypotheses test $(\mathrm{t}$ - test) it was found that:

1. The test value of clan culture is 1.876 , higher than the

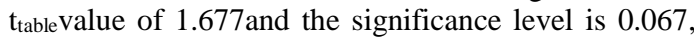
higher than 0.05 . This shows that the clan culture significantly has no influence on employee performance.

2. The testvalue of adhocracy culture is 1.159 lower than the table value at 1.677 andthe significance level is 0.252 , higher than 0.05 . This indicates that adhocracy culture significantly has no influence on employee performance.

3. The test value of market culture is 4.098 , bigger than the value of $t_{\text {table }}$ at 1.677 with the significance level of 0.000 which is lower than 0.05 . This illustrates that market culture significantly influencesemployee performance.

4. The test value of hierarchy culture is -0.130 , lower than 1.677 of the $t_{\text {table }}$ with the significance level of 0.897 , higher than 0.05 . This suggests that hierarchy culture significantly has no influence on employee performance.

Whereas according to simultaneous hypothesis test, it was found that the $F_{\text {test }}$ value of organizational culture is 30.349 , higher than the Ftable value of 2.57 with the significance level of 0.000 which is lower than 0,005 . It means that the organizational culture variable simultaneously has a significant influence on the employee performance. The results of the simultaneous hypothesis are shown in the table below.

Table. 2. Simultaneous Relationship Results

\begin{tabular}{|c|c|c|c|c|c|c|}
\hline \multicolumn{7}{|c|}{ ANOVA $^{a}$} \\
\hline \multicolumn{2}{|c|}{ Model } & Sum of & df & $\begin{array}{l}\text { Mean } \\
\text { Square }\end{array}$ & $\mathrm{F}$ & Sig. \\
\hline \multirow{3}{*}{1} & Regression & 14.072 & 4 & 3.518 & 30.348 & $.000^{\mathrm{b}}$ \\
\hline & Residual & 5.680 & 49 & .116 & & \\
\hline & Total & 19.752 & 53 & & & \\
\hline \multicolumn{7}{|c|}{ a. Dependent Variable: y } \\
\hline \multicolumn{7}{|c|}{ b. Predictors: (Constant), x4, x3, x1, x2 } \\
\hline
\end{tabular}

Coefficient determination is used to test the contribution of independent variable shaping the dependent variable. Based on the test, it was found that organizational culture (clan, adhocracy, market, and hierarchy culture) contributes to shape the performance of tele account management employees for 0.712 or $71.2 \%$ while $28.8 \%$ is caused by other variables not accounted in this research.

\section{Conclusion}

In general, members in the unit of Tele Account Management of PT. Telkom Indonesia Regional VII Makassar already work based on the organizational culture. It also found that they already fulfill the criteria od employee's performance in their daily activity.

This research has found that although employee performance is influenced by the organizational culture, but in the Unit of Tele Account Management of PT. Telkom Indonesia Regional VII Makassar, the employe work based on market culture much more than in clan, adhocracy and hierarchy cultures.

\section{References}

[1] Gimenez-Espin, J.A., Jimenez-Jimenez, D., Martinez-Costa, M. (2013). Organizational culture for total quality management. Total Quality Management Vol. 24, No. 6, 678 - 692.

[2] Fahmi, I. (2013). PerilakuOrganisasi: Teori, Aplikasi dan Kasus (cetakan pertama). Bandung: Alfabeta

[3] Shahzad, F. (2014). Impact of organizational culture on employee's job performance, an empirical study of software houses in Pakistan. International Journal of Commerce and Management, Vol.24, No. $3,219-227$

[4] Sunyoto, D. (2014). Manajemen dan Pembangunan Sumber Daya Manusia. Yogyakarta:CAP

[5] Anissa, M. (2016). Pengaruh Budaya Organisasi Terhadap Kinerja Karyawan PT. Telekomunikasi Indonesia, Tbk (Persero) Witel Sumsel/The influence of Organizational Culture on Employee. Bandung: Telkom University.

[6] Suderman, J. (2012). Using the Organizational Cultural Assessment (OCAI) as a Tool for New team Development. Journal of Practical Consulting, Vol. 4 Iss. 1, 52-58

[7] Yusup, M. (2017). Pengaruh Budaya Organisasi The Telkom Way terhadap Kinerja Karyawan PT. Telkomsel di Area JABODETABEK JABAR. Bandung: Telkom University.

[8] Ahmad, T., Farrukh, F., and Nazir, S. (2015). Capacity building boost employee performance. Industrial and Commercial Training, Vol. 47, No. 2, $61-66$.

[9] Sudarmanto. (2014). Kinerja dan Pengembangan Kompetensi Sumber Daya Manusia. Yogyakarta: Pustaka Pelajar.

[10] Anitha, J. (2014). Determinants of employee engagement and their impact on employee performance. International Journal of Productivity and Performance Management, Vol. 63, No. 3, 308 - 323.

[11] Dantes, N. (2012). Metodologi Penelitian (Research Methodology). Yogyakarta: Andi.

[12] Sugiyono. (2013). Metode Penelitian Bisnis (Business Reseach Methods) (Cetak Ke-17). Bandung:Alfabeta. 